\title{
Clichés of the Soviet Ideology in the Praising Compositions by D. Shostakovich
}

\author{
Natalya M. Naiko* \\ Krasnoyarsk State Academy of Music and Theatre \\ 22 Lenin Str., Krasnoyarsk, 660049, Russia
}

Received 20.12.2014, received in revised form 15.01.2015, accepted 04.02.2015

\begin{abstract}
The oratorio "The Song of the Forests" and the cantata "The Sun Shines over Our Motherland" were created by D. Shostakovich due to "social services commissioning". In the verses by E. Dolmatovsky there is high concentration of clichés endowed with the propagandistic function. In the same way that the official state language approves a set of speech patterns or clichés, in music a special intonation vocabulary is formed. Its basis are typified musical momentum that model the speaker's tone as well as some genre signs that reflect the spirit of the age, representing the ideological principles. In the both compositions Shostakovich used the complex of regulations that were enshrined in the national musical practice of intonation patterns of that period of time, marked by the communist ideology. At that, the elements of the genre model of march, fanfare formulas, etc. display the ability to function separately or in combination with the other elements of the genre models. Connection of the number of typified melodic, rhythmic and textural formulas with a certain range of values, ideas and images in their autonomy and mobility indicates their similarity with the rhetorical decorations - the rhetorical figures. The rhetorical figures, studied in the article differ in their genesis and immediacy of the emotional impact. With that, their joint moments are: communicative orientation and the ability to influence the minds of people, the task of formation of the feeling of belonging to a particular social community, the function of involvement of the audience in a general emotional state and infusion of a sense of pride. The method of composition, based on the principle of combining the elements of the propagandist-agitator's phrase book, bears evidence of creative emancipation of the author and absence of clichés in his consciousness.
\end{abstract}

Keywords: Shostakovich, oratorio "The Song of the Forests", cantata "The Sun Shines over Our Motherland", musical rhetorical figures of the Soviet Russia.

Research area: art history.

The fact of appearance in D. Shostakovich's "creative portfolio" such opuses of allegiance as the oratorio "The Song of the Forests" and the cantata "The Sun Shines over Our Motherland" in different periods of our country life gave rise to a variety of comments. From the official point of view that was expressed by T. Hrennikov in the late forties of the last century, it was a decisive shift of the composer to "a new realistic approach" (Petrov, 2007: 32).

The authors of musicological studies that appeared in the recent years, concerning Shostakovich's musical texts praising the motherland and the party leaders, find an excuse

(c) Siberian Federal University. All rights reserved

* Corresponding author E-mail address: mikinai@ya.ru 
for the comments (with a hint of reproach and regret) regarding his creative compromises. Dmitry Dmitrievich Shostakovich's personal attitude to such opuses is expressed in the following words: "I sat down at night and within a few hours I dashed off something "without much effort". When I brought this composition, to my surprise and dismay, they shook my hand and gave me money" (Beseda, 1996: 242).

At the same time, these compositions can be considered as one of the intermediates of the process of artistic development by the symphony, as a conceptual genre of the musical vocabulary of mass actions of the Soviet Russia. In this case we mean not the historical methods of penetration of the aforementioned intonations through the vocalsymphonic compositions into purely instrumental ones, but crystallization of the new qualities in the well-known pieces of musical language and the level of their detection. This issue is studied in the presented article.

It is a well-known fact that in the Soviet Russia, artistic creativity could not be independent from the party orientation and free from the government control. Each author constantly felt the pressure of the ideological machine and had to comprehend "the greatness of the forthcoming tasks". The main criterion for evaluation of the works of art was the idea of "the party spirit" that was indirectly subordinate to the idea of glorification of the Revolution, the new motherland, the Communist Party, the leaders ${ }^{1}$ and the socialist labour. Through the system of public organizations, creative unions, cultural institutions and "friendly" critics the government "educated" their intellectuals, thus "shaping" artists' ideology. The ideologists of the state of workers and peasants directed authors not only to the certain range of images ("the Soviet people's ways of living” (Danilevich, 1955: 4)) and topics ("of current interest" and "modern" (Reznikov, 1975: 43)), but also to the certain range of expressive means and "democratic" language available for everybody. For the purpose of the so-called "directed influence" music acts in alliance with words as a mean that expresses the ideological purpose in accessible and specific manner. Consequently, it is quite logical that significance of the mass genres songs and marches increased in music and in "academists" creativity the number of choral, vocal symphonic and descriptive compositions enlarged.

It is known that D. Shostakovich's oratorio "The Song of the Forest" (1949) and cantata "The Sun Shines over Our Motherland" (1952) were composed due to "social services commissioning": the oratorio is dedicated to Stalingrad's gardening after the World War II and the cantata is dedicated to the $19^{\text {th }}$ Congress of the All-Union Communist Party of Bolsheviks. The theme that reflected the atmosphere of public events of All-Union importance, the genres themselves that assumed either greatness and the scale of realization of the idea, or grandeur of an action, which is associated with the execution of the officious and glorifying compositions - all this contributed to the fact that the authors used certain vocabulary, in the poetic texts as well as in the music.

In the verses by Y. Dolmatovsky, written specifically for these compositions, especially organized reality was depicted; in fact, it was the mythological model of the world implanted by the state apparatus of the Soviet Union into the minds of its citizens. In the center of the universe there was the social pyramid, enclosed community, named "the Soviet people". Its basis were "the masses", "proletarians" and "farmers" united by "friendship", "brotherhood" and thinking as one and undivided "we". The top of this pyramid are the leaders, the "great" and "wise" party, which "lead the way", "direct" and "teach". Integrity and unity of "the Soviet people" is determined by the feeling, similar to the religious one, "Свято 
выполняя все заветьл Ленина, мы идем за Партией вперед” (the Cantata).

Integrity of the masses is enhanced by the fact that "we" - "the ordinary Soviet people" are opposed to "they" - "the enemies" that were defeated in the past or in the present forthcoming war. Natural elements are also considered as enemies and it is expressed in the following figures of speech: "коварен был июльский зной, полям грозили небеса" (the Oratorio, № 2), “ветер летит окаянныци” (the Oratorio, № 3). That is why there is also struggle with the undesirable natural phenomena, “мы с природой вступаем в сраженье” (the Oratorio, № 7), “объявим засухе войну” (the Oratorio, № 2).

The space in this mythological world is organized in a certain way: "Our Motherland" is illuminated by the sun, and as contrasted to this, the sky of the enemy's land is blotted by the "hostile" and "war" clouds that claim to "our" bright sky. Time is also mythologized. "Difficult" past” with “tough luck” (the Oratorio, № 3) spent “в битвах, суровых сраженьях" and “трудной опасной борьбе (the Cantata) is opposed to the "better" present that leads to "happiness and peace" in the "bright" future. Time vector is directed only forward, «все вперёд и вперёд мы идем”, “Коммунисты, вперёд!” (the Cantata). The feeling of the "new" life is connected with the idea of eternal happy life that lasts for many generations, so it represents a special supertemporal plan: "Под знаменем Ленина идут поколения”. “Ленин с народом всегда и во всем”, «счастье и мир на века”, (the Cantata), “коммунизма век” (the Oratorio, № 2).

In Dolmatovsky's text there is a variety of symbols replicated by social and political newspaper journalism. The symbols of the "transformed" life are: "spring", which "the new world breathes"(the Oratorio, № 2); childhood as the new generation is "growing" and "blossoming" like an orchard (the Oratorio,
№ 4, the Cantata); the sun and sunlight ("Наш путь солнечен и радостен”, “дороги светлы и лучисты" (the Cantata), the days of the "new" life are "sunny" (the Oratorio, № 1 ), for "us", "the dawn of communism is rising" (the Cantata). The idea of the sublime and free motivations is implemented through the images of bird's flight and wings 2 : "eagle's flight" of the people, “Ленин - могучий горный орел”, “мы стали крылаты" (the Cantata).

Confidence in the "verity" of the existing world order was supported by the statement of the ideal of power and wealth that was close and clear to the masses: "Мы” - “сильны и богаты”, “силь нет на свете, чтобы нас сломила" (the Oratorio, № 7). Positive emotions are nourished by a sense of their own power, grandeur and the scale of acts that is declared in the following lines: "we" are directed by "the great party", in our heart "we" have "the great name" of Lenin (the Cantata), "we" turn "the great construction" into reality (the Cantata), "showing wonders to the world" (the Oratorio, № 2). In “великой советской стране” (ibid., № 5) “деревья встают величаво” (№ 7), they will “опояшут шар земной” (№ 5).

In establishment of power, greatness and determination to defend the "right thing" a warlike characteristic often presents, what is manifested in the following lines of the text: "Прекрасная судьба завоевана в битвах”, “пролетарии шли за рабочее дело в последний решительныйбой” (the Cantata). Each member of the new society is considered as a future warrior: "Комсомольские вышли полки” (the Oratorio, № 5), even apple trees must grow "brave” (№ 4), since they are considered as "the soldiers of the Motherland" (№ 7). Some trees are metaphorically defined as "the peaceful army” (№ 5) and “лесные полосы зашичта Родины”" (№ 7).

The following calls are marked by invasive or uncompromising tone: “Счастье возьмем мы 
своими руками” (the Oratorio, № 5), “объявим засухе войну" (№ 2). Readiness to make an extra effort or heroic self-sacrificing act in the past and in the present time of peace also reveals a warlike character in this context: “шли на подвиг в огонь поколенья”, “на подвиг ведут коммунисты” (the Cantata), "Вставайте на подвиг, народы единой советской страны!” (the Oratorio, № 5).

Even a quick overview of some features of the Oratorio and the Cantata's poetic texts allows us to see a large number of clichés endowed by inspiring and propagandist function. “Страна созиданья”, “солнце свободы”, “великое братство”, “светлые дороги”, “знамя Ленинское”, “орлиный полет”, “рабочее дело”, “последний решительный бой”, “мудрая Партия", “счастье и мир на века" (in the Cantata); "многострадальная земля", “горькая доля”, “пионер - всем пример”, “заря коммунизма", “коммунизм наша слава и честь” (in the Oratorio) are among them. A lot of slogans used in the text contribute to the party-state propaganda and involve emotional declamatory intonation, for example: Приблизим коммунизма век!; Вставайте на подвиг, народы, Великой Советской Страны!; Стройся и славься наш город-герой! (the Oratorio); $\mathrm{Mbl} \mathrm{за} \mathrm{солнце,} \mathrm{за}$ счастье, за мир! Ленинской партии слава! (the Cantata).

In the same way that the official state language approves a set of speech patterns or clichés, in music a special intonation vocabulary is formed. Its basis are typified musical momentums that model declamatory intonation, as well as some genre signs that reflect the "spirit of the age", with various degrees of immediacy representing ideological principles.

Explicit officious orientation of the oratorio "The Song of the Forests" and the cantata "The Sun Shines over Our Motherland" by D. Shostakovich determined use of the standard confirmed intonation patterns enshrined in the national musical practice of that period of time and marked by the communist ideology. It is a well-known fact that in the music of the Soviet period the priority was given to such mass genres as songs and marches. They were endowed with "the spiritual and practical functions", including organizational function, propagandist and agitational function and ideological function as the most important socially (Sokhor, 1980: 237).

The genre of march that expresses the "revolutionary pathos of the masses" (Solodovnikov, 1985: 28), "heroic" and "patriotic" spirit of the ideals and aspirations, became a kind of a symbol of the communist consciousness and the Soviet era. In the obviously officious oratorio and cantata by Shostakovich the characteristics of this genre are embodied as fully as possible, directly and specifically. In the oratorio the march's song was the basis of №4 “Пионеры сажают леса" and №5 “Комсомольцы выходят вперед". In the cantata use on this model is visible occasionally, mostly in the words:

«Под знаменем Ленина идут поколения» (w. 9)

«Пролетарии шли за рабочее дело в последний решительный бой» (w. 17);

«Под знамя Советов Отчизну привел Ленин могучий - горный орел» (w. 19);

«Сила дружбы и братства народов проверялась в сраженьях огнем.

Для людей покоряя природу, всё вперед и вперед мы идем» (w. 25).

At that, in both compositions, typified and recognizable elements of the march genre model reveal the ability to function outside the integral complex of musical and expressive means, independently or in combinations with the different independent elements of the other genre models (e.g., dancing). In such cases a genre model can be represented by the shortest formula - melodious, texture, rhythmical, 
timbre - often associated with the same typified idiom. The connection of such formulas with a certain range of meanings, perceptions, ideas and images in their autonomy (syntactic and texture) as well as their mobility, indicate their similarity with the rhetorical decoration figures of speech.

In the cantata a kind of figure of speech, which can be defined as "heroic march" was crystallized. The definition of "heroic" is determined, on the one hand, by the text content (which phrases the idea of struggle and battles for the communist ideal) and on the other hand - by the musical means that deliver the special mood of uplift, determination and commitment.

The value of the figure of speech in the "heroic march" is acquired by the small structures, usually sentences, that contrast with the surrounding material due to its texture, melodic and rhythmic organization (the Cantata, w. 17 “Пролетарии шли за рабочее дело в последний решительный бой” - 4 bars; w. 19 "Под знамя Советов отчизну привел Ленин могучий горный орел” - 4 bars, w. 25, “Сила дружбы и братства народов проверялась в сраженьях огнем. Для людей покоряя природу, всё вперед и вперед мы идем." - 8 bars). The basis of the "heroic march" figure is the fanfare tone that penetrates not only into the orchestral structure, but also into the choral parts. It is manifested in a number of ways: by rising iambic trichords; rising and falling iambic quartal motifs; in alternatives of the "golden horn" (Fig. 1).

Along with the complex figure of the "heroic march" in the Cantata and the Oratorio the drums formulas, typical for the genre of march, also acquire the value of the figures of speech. The specific function of percussion instruments is often embodied by Shostakovich conditionally. It happens, firstly, because of the peculiar timbre substitution, which meaning evolves execution of a rhythmic shock formula by the instruments with different nature of intoning (brass or string). Secondly, the rhythmic function is performed by the sound of the short pieces such as repetitions, mordents, gruppetto and trills. A clear rhythmic organization, emphasized metric tone and repetition of rhythmic groups lead to the shift of

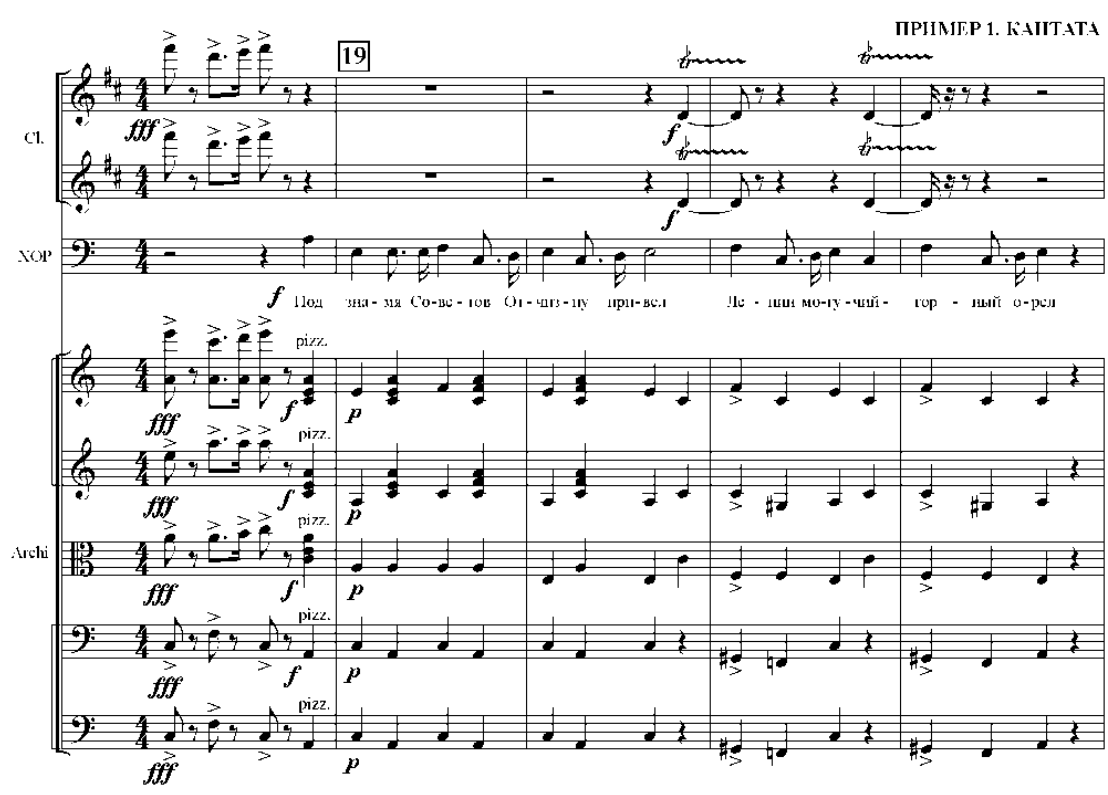

Fig. 1 
the melos to the back burner, and this fact creates the conditions for such functioning.

The maximum direct function of the percussion instruments is represented by the constant repetition of the same tone which is rhythmically organized into the groups of eighth

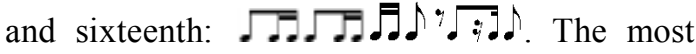
appropriate definition for such figures is "the side drum formula”. In № 4 of the Oratorio (w. 50) in particular, the first of the abovementioned rhythmic formulas is executed by the side drum and in w. 54-by the strings. In № 5 of the Oratorio (w. 65) "the side drum formula" is performed by the violins.

Another figure, associated with the traditional use of the side drum in brass bands is so-called "drum roll". It can be represented by the repetitions of one tone a tempo allegro or by a trill. In w. 22 of the cantata in the four-bars orchestral overture, triple pulsation of the eights executed by the side drum and timpani (tone "e") contributes to the creation of an aggressive melody, typical for the military march and serves a kind of illustration to the text that follows it: "В жестоком бою за честь и свободу свою сражался советский народ”. It is prominent that at the time when the chorus starts singing, the same rhythmic function (triple pulsation of the eights, $f f$ ) is delegated to violins and violas and at that, violins' tone is " $e$ ". Thus, in this case, the typical formula of the percussions, implemented in the part of other musical instruments, which have different melodious sounding, is used as a figure of speech.

Sound imitation function of the abovementioned rhetorical figures is particularly evident under certain dynamic and register conditions: loud and energetic sound, high register, not frequent trill - all these contribute to creation of the noise effect of the drum roll. For example, in the fifth part of the Oratorio №5 (4t. to w. 59) in the part of the woodwinds in the high register a figure of speech "drum roll" sounds to $f$ with dynamic fade in (crescendo). In the case of appearance of the figure "drum roll" in the form of the abovementioned trill, organization of the trill in the groups of sixteenth provides sound with clarity, metric clearness and brings the trill closer to the percussion formula.

The figure of the "drum roll" can be represented by various short formulas. In the Cantata (w. 19) in the part of the clarinet drum roll effect is reproduced by the loud and active sound of the short groups of the trill (see Fig. 1). The figures of the short trill, reproduced by the sixteenths are also possible. Sometimes Shostakovich reproduces the "drum roll" with the help of mordents and gruppetto. As a result, due to deliberate accentuation of the basic tone that appears in each metric share, the melodious function is neutralized. A figure of the similar type is used in the middle cadence of marching introductory section of the fifth part of the Oratorio, which denotes its genesis (in the part of the wind wooden instruments -4 t. to w. 55).

A figure, based on the ostinato repetition of the basses beat (in the parts of the faggots, tubas, cellos and double basses).$\Gamma$ at the same pitch (ц. 58, 60, 61) appears in the Oratorio. For this figure it is possible to offer a definition of "the bass drum formula" (because this musical instrument is usually used for execution of the simple rhythm sections).

Another figure, which is genetically related to the genre of march and represents this genre model not only at the level of the intonation patters, but also at the structural level, is a figure that was conventionally named "march ritornelle". Instrumental ritornellos in the marching songs are used for marking the boundaries of different formations (sentences and periods) and provide structural definition and clearness of syntax and composition. For example, in № 4of the Oratorio "Пионеры сажают леса" the ritornelle, based 
on the fanfare motifs of entrance that imitate the signal of the pioneer horn, is played before each new verse directly serving its purpose.

The moment of the marching structure declaring, its deliberate exposure in the works that have nothing in common with the application function, makes it possible to refer such ritornellos to the category of the figures of speech. In the Cantata and the Oratorio they, as a rule, appear at the end of each line of the text (following the sound of the choral part) that corresponds to the boundaries of phrases and sentences of the period (the Cantata: w. 25, 19 - in the lines, every 2 t. see Fig. 1; the Oratorio: w.63, 65 - at the end of each line of the text - i.e., $3,4 \mathrm{tt}$.). This kind of figures often includes typical rhythmic formulas of march: short "drum roll" (the Cantata, w. 19) and fanfare motifs in dotted rhythm (the Cantata, w. 25 - Fig. 3). Particular solutions, when "march ritornelle" have different intonation patterns, draw attention: figurations, as if illustrating the flying flags in the chorus "Выле знамя!" (the Oratorio: № 5, w. 63, 65 - Fig. 2). In this case, the function of "march ritornelle" is indicated by the genre context and structural position.
"March ritornellos" are characterized by timbre, texture and dynamic isolation (which are means of their accentuation and point at their functioning as figures of speech). Thus, in the Cantata in w. 19, this figure of speech, in the part of the Clarinet (the only involved wooden instrument) sounds to $f$; in w. 25 - in the high register of the flutes and clarinets (the wooden instruments are used in this musical structure for the first time ) - to ff. In the Oratory, № 5, in w. 63 figurations in the parts of the wooden and string instruments stand out from the chord context and in w. 65 the wooden instruments are played only during the "march ritornelle", to $f f$.

Another figure that can be named “accompaniment viola formula" also refers to the marching figures. It includes syncopated chords of the copper instruments: " $\$$ or ${ }^{t}$ ". Thanks to the timbre solution these chords are associated with a typical element of the marching accompaniment, as if devoid of bass support (usually performed by the tube) and played by violas of a brass band. Independence of the "accompaniment viola formula" is expressed in its mobility, its free combinations with the

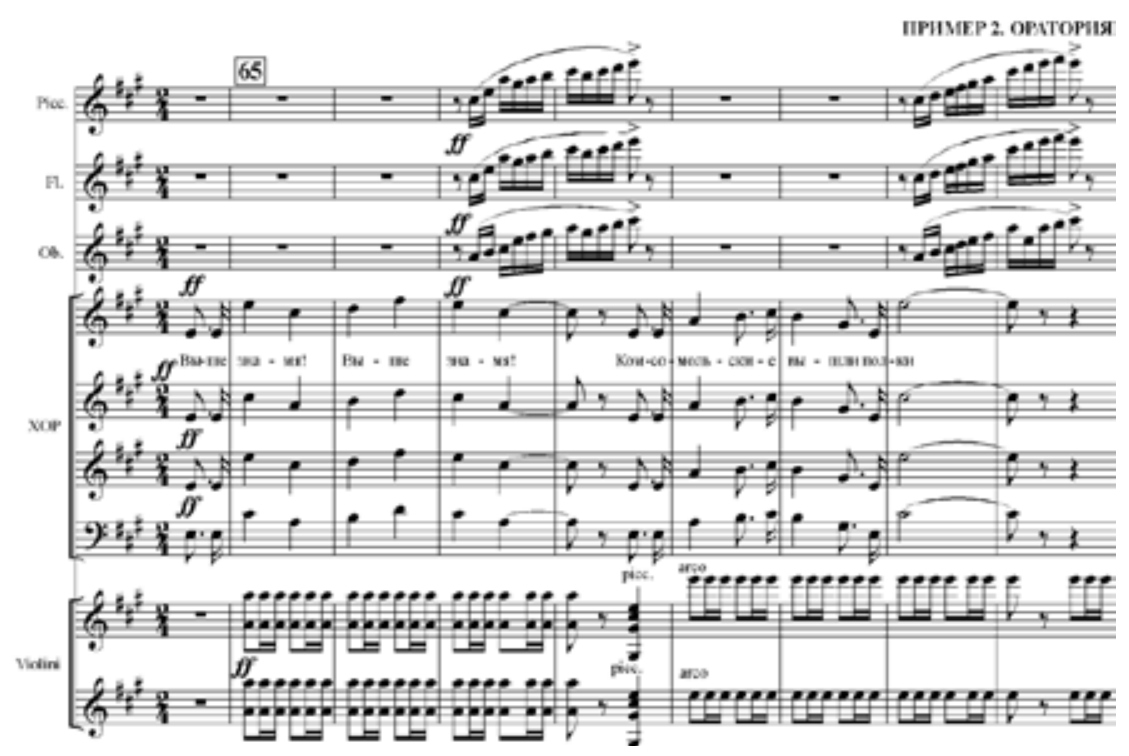

Fig. 2 


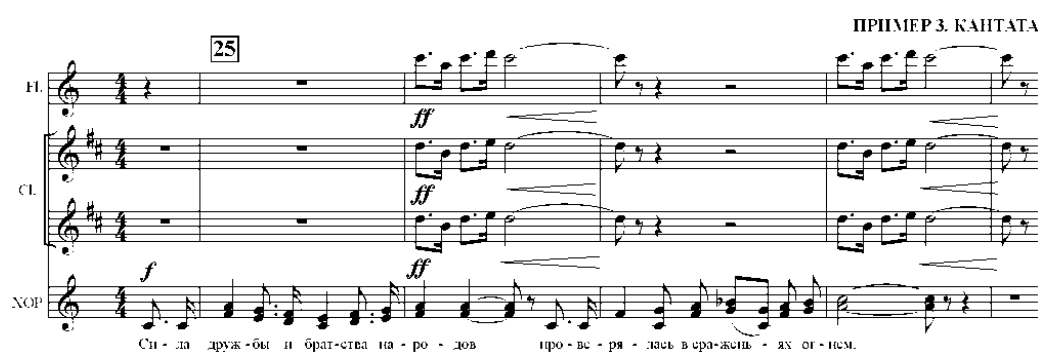

Fig. 3

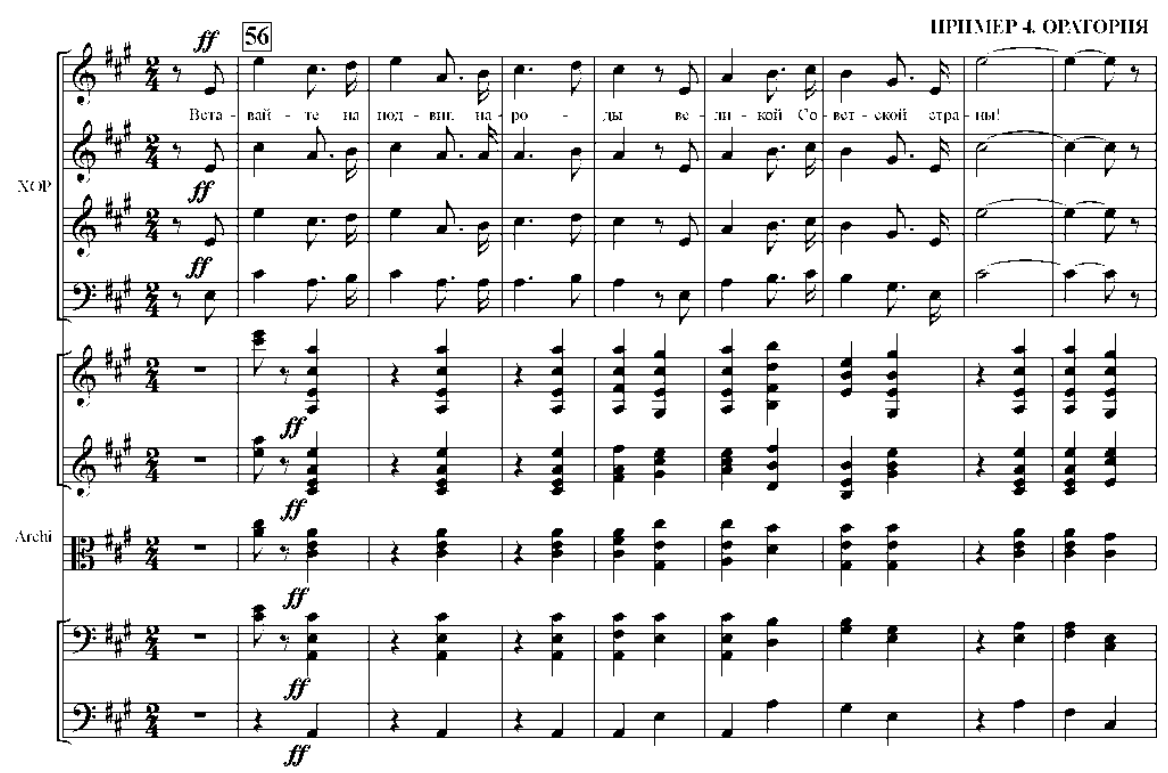

Fig. 4

other genre material and in its timbre mediation, as, for example, it sounds in the part of fagotts and double-basses that intensify the effect of illustration, as in the Oratorio, $7 \mathrm{t}$. before w .58 (See Fig. 4: the first three bars).

The most important intonation characteristic of the Cantata and the Oratorio is fanfare. It is determined by implementation of different signal formulas - the "viola's golden step", steps by the sounds of chords, etc., that permeate the musical of many episodes of these compositions. In the compositions, intended for the concerts, devoid of the direct everyday functioning, fanfare loses its direct purpose of the alarm call, cry and, according to Nazaikinsky's words, acts as a “depicted call" (Nazaikinskii, 1982: 118). Emergence of the fanfare idioms in the introductory sections and sounds of the brass instruments contribute to conservation and direct identification of the signaling function.

These are brief introductions to the sections of the contrast-component form of the Cantata: rhythmic formula لـ o of the trumpet (w. 11 t. 6), long signal of the violas with the dotted upbeat ( 2 t. to w. 25 ), the introduction to № 4 of the Oratorio with the signals of the Pioneer horn played by the trumpet (w. 44) as well as triplet repetitions by the trumpet and the trombones in 
the transition to the code of the Oratorio (w. 102). In many cases, while keeping the composition position (introduction), timbre substitutions enhance the effect of the signal's "illustration", which creates conditions for the formation of the "fanfare" figure. One of the version of this type of figure includes signal formula, embodied by the timbre complex: the brass instruments (French horn) and woodwinds (oboes, clarinets and faggots) - the Cantata, w. 15 t. 10.

The effect of signal's illustration is amplified when the fanfare idiom is performed in tutti, and the tone of the brass instruments loses its dominant role (as in the Cantata before w. 19 see Fig. 1). The larger degree of conditionality is achieved when the fanfare idiom is performed by the instrument with uncharacteristic for this type tone timbre (wood or string). For example, in the introduction to № 4 of the Oratorio (w. 46), the signal of the tube is imitated by the flute and clarinet. In № 5 of the Oratorio the "fanfare" starts orchestral introduction and appears in the part of the wooden instruments (w. 54) and then in the string part (w. 55).

Shostakovich introduces a figure of the "fanfare" not only in the introductory sections, but also inside its compositions. Its representational function becomes obvious in the certain moments of the text illustration, in particular, the "fanfare" in the parts of the violins and violas (triol repetition formulas) is accompanied by the words "звучал призыв" (the Cantata, 2 t. to w. 24 - Fig. 6). At the same time, compositions of the signal type (rising iambic trihord in sopranos' and tenors' parts, quart ascending motifs in bass' and alto's parts) that are also used as this figure, appear in the choir's part. Inside the compositions the "fanfare" figure is emphasized as a result of the certain textural and register conditions. Thus, at the time of its introduction in the Cantata, in the string part of the aforementioned example, the type of texture presentation changes (from the chordal one during repetition), and at that, thanks to the octave doublings, the high register is used.

The figure of the "fanfare" is frequently introduced into the composition regardless of the text content and compositional function of a section. The fourth part of the oratorio ("Пионеры сажают леса") not only uses the tube motif, depicting pioneer signal horn, but it has numerous signal formulas in the chorus, woodwinds and string instruments parts. In the same part this figure is also included in the strings' (4 t. to w. 49) and woodwinds' (w. 50 t. 4 : flute, clarinet) part and represents the steps with splitting unison, repetition formulas, "golden horn" or compositions that are similar to them. Losing the function of the signal representation, the "fanfare" figure in the aforementioned fragments has another function - the expressive one, helping to create a solemn-uplifted or heroically-aggressive mood.

It is noteworthy that the "fanfare" is an important element of the choral part, attracting attention due to the typical structures of the constructions used in it and their structural position. For example, this figure is represented in the Cantata, in w. 23, in the lines of all the choral voices by chanting in $f f$ dynamics of one tone, following the words " $И$ как сердия приказ”. (In w. 7 of the Cantata in the boys' choir part with the words "Все наши дороги светль и лучисты" the similar signal formula in octave presentation was used more conventionally by the quiet dynamics). In w. 24 the phrase of call by the choir "Коммунисты, вперед!" is represented by the "golden horn formula" that are duplicated by the groups of wooden and brass instruments (Fig. 5). In the fifth part of the Oratorio eightmeasure composition that performs the function of the refrain (for the words "Вставайmе на подвиг, народы, великой Советской страны!"”) begins and ends with fortissimo by anticipated rising octave step, modeling fanfare signal-call. 


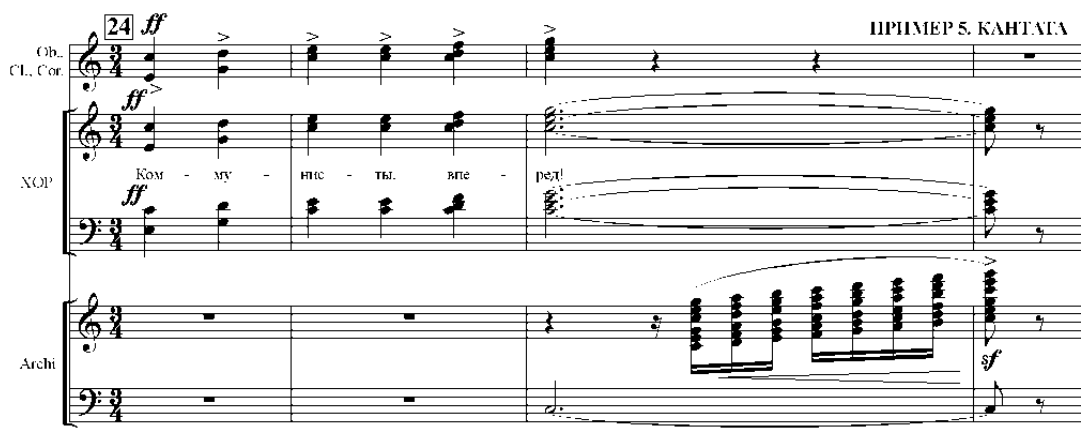

Fig. 5

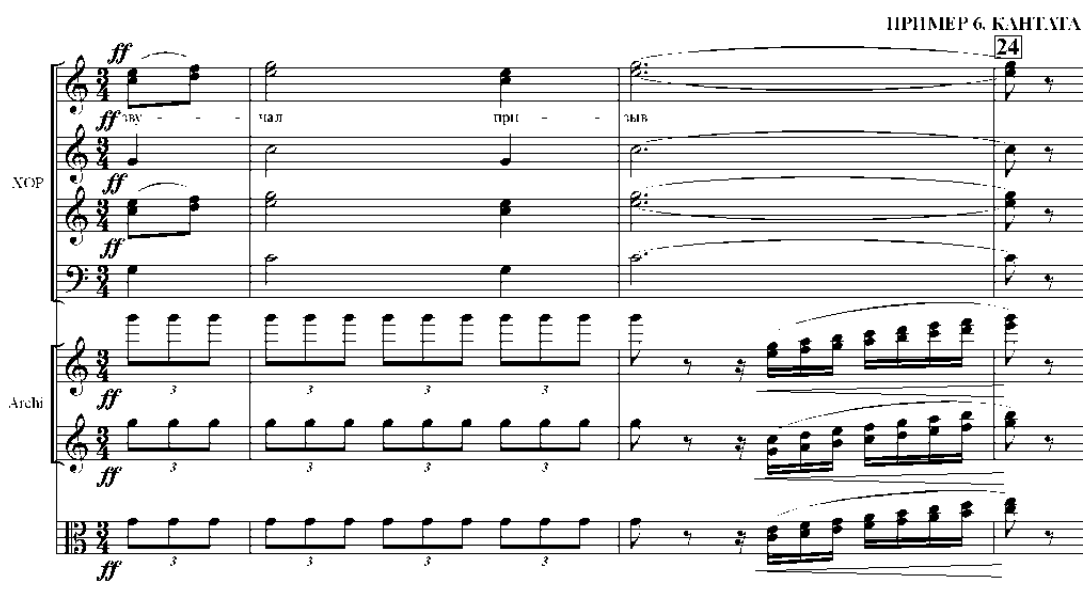

Fig. 6

Furthermore, it has a typical signal step with split unison (see Fig. 4).

Thus, the fanfare tone reflected in the figure of the "fanfare" dominates in the analyzed compositions, forming its thematic material. It becomes the style tone, representing the officious, propagated by the government of the Soviet era style of music. Being a genetic exponent of the certain range of emotional states (solemn, pathetically-elevated, heroically-aggressive and belligerent), it as if identifies the underlying characteristics of the "Soviet people" community and emphasizes its mentality.

In addition to the figures which are based on the typical genre formulas, the figures, based on modeling of the elevated declamatory intonation can also be found in the Cantata and the Oratorio. Since they are connected with the content of the text and express the call to action, as well as proclamation of any ideas, glorification of the party, the socialist state and its leaders, they can be described as figure-“slogans”. For example:

- "slogans-calls" in the Cantata: «Коммунисты, вперед!» (w. 24,26,43), in the Oratorio: «Оденем Родину в леса!» (w. 18,20,22,24,28), «Вставайте на подвиг, народы, единой Советской страны!!» (w. 56), «Bblше знамя!» (w. 60,63,65,68);

- "slogans-proclamations" in the Cantata: «Коммунисты всегда впереди» (w. 8 t. 5), «Коммунизм построит наш народ» 
(w. 37 t. 4), in the Oratorio: «Правда с нами и счастье у нас» (w. 103), « $\mathrm{Mbl} \mathrm{за}$ солнце, за счастье, за мир!» (w. 108);

- "slogans-glorifications" in the Oratorio: «Слава командирам битвыз за природу» (w. 97), «Ленинской Партии слава!» (w. 110), «Слава народу навек!» (w. 110 t. 5), «Партии мудрой слава!» (w. 111).

The function of the figure of "slogan" is accentuation, as well as expressive and prominent presentation of the ideologically important phrases. The similar effect is achieved, firstly, by the special structural position of this figure. In some cases it is introduced at the beginning of a stanza ("Вставайте на подвиг, народы”, "Выме знамя!"), in others - at the end of a stanza, standing out due to its cadence position (“Коммунисты всегда впереди”, “Коммунизм nостроит наш народ!”). Sometimes a "slogan”, being the last line of a stanza, and performed twice functions as a chorus (“Оденем Родину в леса!”, “Коммунисты, вперед!”).

This function also determines the type of intoning, which is based on modeling the exaggerated-elevated declamatory intonation, thus, most of the "slogans" are began by the "calling" ascending fourth step, moreover, some of them end with iambic motif that contain an ascending change to the fourth, sixth or octave (see Fig.S 2, 4, 7). The use of "catchy" and "expressive" fanfare steps is typical for this figure: common chords moves with filling the steps by diatonic passing tones and the "golden horn" (Fig. 5). The general slogan intonation becomes the intonation of exclamation that covers the entire structure of a "slogan" by crescendo ascending motion, directed to the top - the climax, often represented by the extended tone.

The considered figure can also be distinguished from the context, not only due to the change of the genre models and musical vocabulary, but also due to the special textured representation by the bar consolidation (in particular when changing the ternary meter to the quadruple meter), growths of the texture capacity (during the transition from monophony to threevoice texture) and dynamics intensification. A good example is the "slogan" "Оденем Родину в леса". Such consolidation is typical for the figure of “elevation" (Fig. 7).

In the Oratorio’s code (№ 7 “Слава”) there is a special case where the structural position of a "slogan" is irrelevant. In accordance with the compositional and dramatic function of the section, intended not only for the conclusion, but for elevation and the praising as well, exclamatory tone of a slogan penetrates the entire coda. Separate phrases that are tonally similar to the figure of the "slogan", are found side by side with the "slogans": "Mы за солнце, за счастье, за мир", "Правда с нами и счастье у нас". Many melodic phrases, as well as the figures of "slogans" are often ended by the lasting sound and are separated from each other by a pause, which

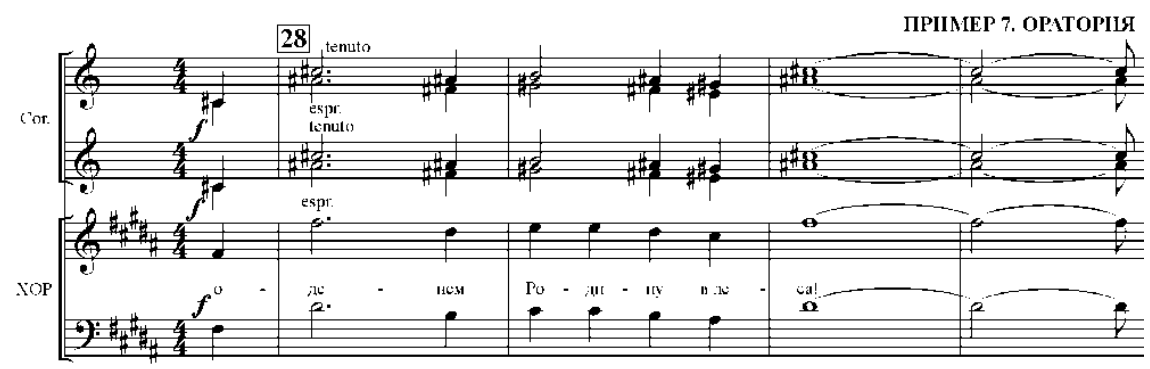

Fig. 7 
gives weight to the pronounced phrases. Due to the slow tempo (Andante) the "slogans" become larger, and the nature of praising brings them closer to the figure of "elevation". It is directly or indirectly related to validation of an idea of greatness in the texts of praising and elevating nature (in the Cantata "великое братство" - w. 28, "Большевистская мудрая Партия" - w. 18, “заветы Ленина" - w. 36; in the Oratorio: “Партии нашей слова!" - № 7, w. 99, “Славя урожай!” - № 4, w. 53, t. 4, “Счастье возьмем мы своими руками, землю родную украсим садами" - № 5, w. 57)

Genetically the figure of "elevation" is associated with the hymn and fanfare genre sphere that is why triad, tetrad, ascending, descending and affirmative tones become its intonation basis. The idea of elevation determines peculiarities of the harmonic and rhythmic composition. Firstly, this figure is characterized by introduction of the tonic pedal point that creates an effect of slowing down the harmonic motion, thus, consequently, an effect of slowing down or a specific stop in time. Secondly, the appearance of the figure of "elevation" is always associated with consolidation of the metric beats of the respective measure and duration, which is accompanied by a change of time (from $4 / 4$ to $3 / 2$ with the words "стали крылаты, сильны и богаты”", the Cantata, w. 5 t. 8 , from $3 / 4$ to $3 / 2$ with words “великое братство”- w. 14 t. 5 - Fig. 8).
In such cases, the motif is presented as if in a "close-up". At the time of this figure appearance the rhythmic pattern may change: for example, "великое братство" syllable chant (the Cantata, w. 6 t. 7) includes a triolic pattern that is the reason why the motif is syntactically growing, changing the character of movement, introducing the idea of the proud and solemn chanting. A similar effect appears during the use of the figures of long rhythmic values that leads to a "poster" representation of a phrase ("Счастье возьмем мы своими руками, землю родную украсим садами" - the Oratorio, № 5, w. 57; "Партии намей слава! - the Oratorio, № 7, w. 99 - Fig. 9, "Большевистская мудрая партия смело массы вела за собой” - the Cantata, w. 18).

The possibility of interaction and interpenetration of the figures of "slogan" and "elevation" is explained by their fundamental relation, based on the enthusiastic oratory and fanfare intonation as well as on the common tasktextured and expressive representation of the ideological attitudes, their elevation to the most important and significant level. Accentuation of greatness, grandeur and power as well as declaration of these qualities contribute to the function of infusion and propaganda, which every power needs, «"it should constantly" "boggle the imagination", as "it is impossible to obey what does not seem "authoritative"» (Vysheslavtsev , 1994: 77).

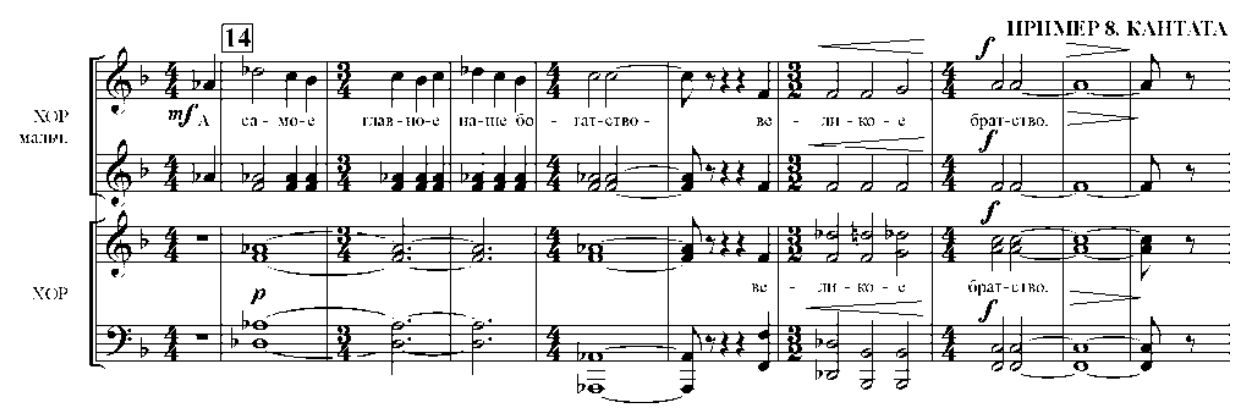

Fig. 8 


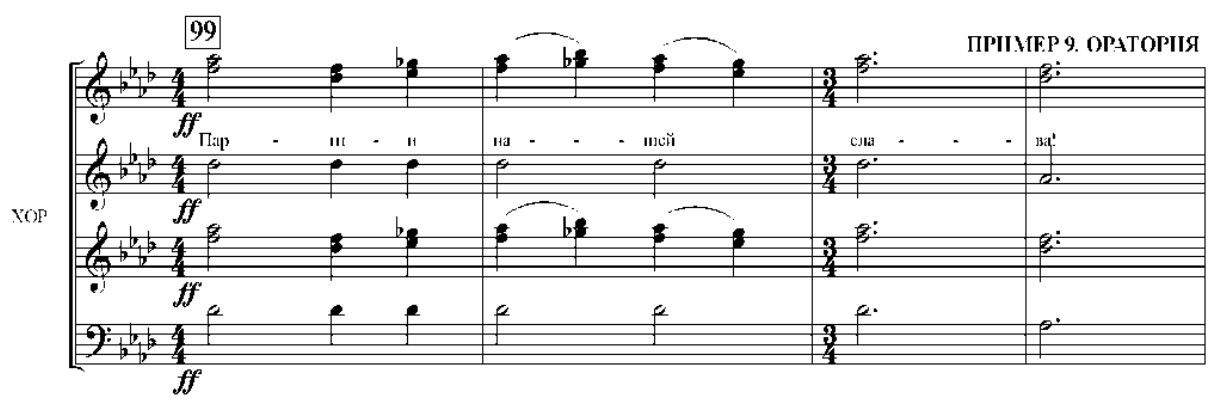

Fig. 9

It is interesting to note that Shostakovich also found opportunities for ingenious modeling of the exclamation prosody only by the use of instruments, which is so presentational for the mass actions related to the public holidays. In the final cadencies of the fast compositions of the Oratorio (Allegro № 2, w. 28, Allegretto № 4, w. 53, Allegro con brio № 5, w. 68), on the borders of the quick parts of the Cantata (w. 18 t. 7; $2 \mathrm{t}$ to w. 22) the stable complex of the expressive means that express joyful uplift, delight and exaltation is emphasized and gets the value of the figures of speech. Taking into consideration the graphic figure of the melody which is based on the ascending passages, tremendous dynamic growth with the removal of the last rhythmic value to $s f$, phonism of the major tonic triad and stability of the function of structural position (conclusion) this figure can be specified as "exclamation mark". It also implies the completeness and grandeur of the sound that is achieved through the texture organization and timbre patterns (see Fig.S 2, 5, 6).

The abovementioned figures differ in their genesis and directness of the emotional impact. However, their joint moments are: communicative orientation and ability to influence people's minds; the aim to form the feelings of belonging to a particular social community; the function of involving of the audience into a common emotional state and infusion of the feeling of pride. In this case, foundation on a word and well -known genre models specifies the effect of certain figures, determining their ideological orientation. On the other hand, such figures as "exclamation mark", "slogan" and "elevation", being more conditional in musical settings has an infecting emotional impact

The above-described figures do not exhaust the rich tonal vocabulary of the composer and his brilliant command of the vocabulary of his period. The very fact of their crystallization and extensive use of the semi-official compositions is quite natural, and it is obvious that in addressing to the specific language models Shostakovich is not original and he corresponds to the "rules of the game". However, the composition method, which is based not on the immediate deployment of intoning, what is peculiar to the nature of Shostakovich's gift but on the game principle of combining the elements from the propagandistagitator's "phrasebook" bears evidence of the author's detachment, his creative emancipation and non-standard consciousness. Shostakovich's work with the musical figures and figures of speech of the "Modern Age" is similar to Mussorgsky's work with the stylistic models of the vocal composition "Classic", where, on the one hand, the author accurately reproduces the musical vocabulary of the Classical period, and on the other hand, it is concentration of various melodic and textural formulas within the 
expositional period along with explicit illustrative function of the musical and expressive means that manifest the author's irony.

It is an interesting fact that not only the vocal-symphonic works by D. Shostakovich, but the sonata's allegro and optimistic conclusions of the sonata-symphonic cycles abound with the musical figures and the figures of speech of the "new Russia". Detailed analysis of the scores reveals consistent patterns in operating of these elements and identifies the original technique of working with them, which allows the composer to reproduce the atmosphere of public celebrations conditionally and with detachment. It also highlights independence of the author's thoughts.

Thus, the author who does not identify himself with the mindlessly cheering crowd, leaves a niche for himself in the artistic space of his compositions, keeping the ability of critical evaluation of the events and manifestation of his personal position.

1 Whose image, according to K.N. Tendit, who means I.V. Stalin, "in people's conscience as well in the state ideology $<\ldots>$ turns into the attribute of the Soviet state, such as the state flag, the anthem and the coat of arms" (Tendit, 2011: 106).

2 It is noteworthy that there are a large number of such symbols in one of the first works of monumental art of the Soviet period, for example, the relief sculpture "Glory to the Fallen in the Struggle for Peace and the Brotherhood of Nations" (1918). It represented the Genius of Fame, and behind his overspread wings the sun with rays is rising, and the rays form the words "The October Revolution" (Istoria..., 1989: 329).

\section{References}

1. Beseda Nelli Kravets c El'miroi Nazirovoi (A Conversation between Nelli Kravets and El'mira Nazirova) // D.D.Shostakovich: Collected Works on the $90^{\text {th }}$ Birthday Anniversary / Ed. by L. Kovnatskaia. SPb.: Kompozitor. 1996. 400 p.

2. Vysheslavtsev B. Etika preobrazhennogo erosa (Ethics of the Transformed Eros). M.: Respublika. 1994. P. 368.

3. Danilevich L. O Sovetskom Simfonizme (About the Soviet Symphonic Style) // Sovetskaia muzyka. 1955. № 4. Pp. 3-12.

4. Istoriia Russkogo I Sovetskogo Iskusstva (The History of Russian and Soviet Art)/ ed. by D.V. Sarab'ianov. M.: Visshaia Shkola. 1989. P. 447.

5. Nazaikinskii E.V. Logika muzukal'noi kompozitsii (Music Composition Logic). M.: Muzyka. 1982. $319 \mathrm{p}$.

6. Petrov V.O. Tvorcheskie kompromissy Dmitriia Shostakovicha v kontekste istorii XX veka (zametki na poliakh biografii khudozhnika) (Creative Compromises of Dmitri Shostokovich within the Framework of the $20^{\text {th }}$ Century History (Notes in the Margins of the Artist's Biography)) // D.D. Shostakovich Creativity Within the Frames of the World Creative Space: International Scientific Conference Proceedings 1-2 March 2007 // Editor-in-chief L.V. Savvina. Astrakhan": Izd-vo OGOU DPO AIPKP, 2007. Pp. 17-46.

7. Reznikov A.M. O roli mirovozzreniia v tvorchestve kompozitora (About the World View's Role in the Composer's Oeuvre). M.: Muzyka. 1975. 56 p.

8. Solodovnikov G. Sotsialisticheskii realizm i muzyka sotsialisticheskogo obshchestva (Socialist Realism and the Socialist Society Music). M.: Muzyka. 1985. P. 39.

9. Sokhor A. Voprosy sotsiologii i estetiki muzyki (Music Sociology and Aesthetics Issues), Iss.1. L.: Sovetskii Kompozitor. 1980. P. 237. 
10. Tendit K.N. “Liubimyi I.V. Stalin!” (sotsial'no-psikhologisheckie aspekty “kul'ta lichnosti”) ("Beloved I.V. Stalin!" (Social and Psychological Aspects of the "Cult of Personality")). Culturology Questions 6/ 2011. Pp. 104-109.

\title{
Клишированная лексика советской идеологии в славильных сочинениях Д. Шостаковича
}

\author{
Н.М. Найко \\ Красноярская государственная академия музыки и театра \\ Россия, 660049, Красноярск, ул. Ленина, 22
}

Создание Д. Шостаковичем оратории «Песнь о лесах» и кантаты «Над Родиной нашей солнце сияет» было данью "соизаказу». В стихах Е. Долматовского высока концентрация трафаретных оборотов, наделенных пропагандистской функцией. Подобно тому как в официальном государственном языке утверждается набор шаблонных выражений, языковых клише, в сфере музыкального языка формируется особый интонационный словарь. Базой для него становятся типизированные музыкальные обороты, моделирующие ораторскую интонацию, и некоторые жанровые знаки, отражающие дух эпохи, репрезентирующие идеологические установки. Шостакович в обоих произведениях использует комплекс нормативных, закрепленных в отечественной музыкальной практике того времени интонационных моделей, отмеченных печатью коммунистического мировоззрения. При этом элементы жанровой модели марша, фанфарные формулы и т.д. обнаруживают способность функционировать обособленно либо сочетаясь с элементами иных жанровых моделей. Связь ряда типизированных мелодических, ритмических, фактурных формул с определённым кругом значений, идей, образов при их автономности и мобильности указывает на их подобие риторическим dесогаtion - тропам. Рассмотренные в статье риторические фигуры различаются по своемугенезису и непосредственности эмоиионального воздействия. Вместе с тем их общими моментами остаются: коммуникативная направленность и возможность влиять на сознание людей; задача формирования умассы людей ошущения своей принадлежности к определенной сочиальной общности; функция вовлечения слушателей в некоторое общее эмоциональное состояние, внушения чувства гордости. Метод композиции, основанный на принциие комбинирования элементов из фразеологического словаря пропагандиста-агитатора, свидетельствует о творческой раскрепощенности автора, незаштампованности его сознания.

Ключевые слова: Шостакович, оратория «Песнь о лесах», кантата «Над Родиной нашей солние сияет», музыкально-риторические фигуры советской России.

Научная специальность: 17.00.00-искусствоведение. 